\title{
ANALISA DETERMINAN YANG BERHUBUNGAN DENGAN KUNJUNGAN PEMERIKSAAN KEHAMILAN (K4)
}

\author{
Murti Wuryani $^{1}$, Aisyah $^{2}$ \\ ${ }^{1,2}$ AKBID Yayasan Konawe \\ E-mail : $\underline{\text { murtiinara@gmail.com }}$
}

\begin{abstract}
ABSTRAK
Penilaian terhadap pelaksanaan pelayanan kesehatan ibu hamil dapat dilakukan dengan melihat cakupan K1 dan K4.Cakupan K4 adalah cakupan ibu hamil yang telah memperoleh pelayanan antenatal sesuai dengan standar, paling sedikit empat kali di suatu wilayah kerja pada kurun waktu tertentu Cakupan pelayanan kesehatan ibu hamil K4 di Indonesia dari 86,85\% pada tahun 2013, terjadi penurunan 86,70\% di tahun 2014, kemudian mengalami peningkatan kembali di tahun 2015 yaitu 87,48\% dan kembali terjadi penurunan di tahun 2016 yaitu $85,35 \%$ (Kemenkes RI, 2016). Tujuan penelitian adalah untuk mengetahui faktor yang berhubungan dengan kunjungan pemeriksaan kehamilan K4 di Wilayah Kerja Puskesmas Wawotobi Kabupaten Konawe tahun 2018. Metode penelitian dengan pendekatan kuantitatif menggunakan rancangan cross sectional. Sampel dalam penelitian ini adalah sebagian dari ibu hamil trimester III yang tinggal di Wilayah Kerja Puskesmas Wawotobi Kabpaten Konawe tahun 2018 berjumlah 42 sampel instrument yang digunakan adalah kuesioner, hasil penelitian di analisa menggunakan chi-square. Hasil penelitian ada hubungan antara paritas dan dukungan suami dengan kunjungan pemeriksaan kehamilan K4, dengan nilai dan tidak ada hubungan antara pendidikan, pekerjaan, jarak rumah kefasilitas kesehatan dengan kunjungan pemeriksaan kehamilan K4.Kesimpulan dalam penelitian faktor yang berhubungan dengan kunjungan pemeriksaan kehamilan K4 adalah paritas dan dukungan suami.
\end{abstract}

Kata Kunci : Kunjungan ANCK4; Pekerjaan; Paritas; Jarak rumah kefasilitas kesehatan; Dukungan suami

\section{THE INFLUENCING FACTORS OF PREGNANCY CHECK OF PHASE 4 AT WAWOTOBI HEALTH CENTRE IN KONAWE}

\begin{abstract}
An assessment of the implementation of health services for pregnant women can be done by looking at the coverage of Phase 1 and Phase 4. The coverage of phase 4 is women who have obtained antenatal care according to standards, at least four times in a work area at a certain time period. The data of health ministry in 2016 showed that the coverage for phase 4 pregnant women in Indonesia was $86,85 \%$ in 2013 , a decrease of $86,70 \%$ and $85,35 \%$ in 2016). The purpose of the study was to determine the factors associated with phase 4 antenatal care visits at Wawotobi Health of Konawe Regency. Research method used quantitative approach using cross sectional design. The sample in this study was the third three-semester pregnant women who live at Konawe Health Centre in 2018 with total 42 samples. The instruments used questionnaires, the results of the study were analyzed using chi-square. The results of this study there is a relationship between parity and husband's support with phase 4 antenatal care visits because there is no relationship between distance of home, education, to health facilities with Phase 4 pregnancy checkup visits. This study related to Phase 4 antenatal care visits are parity and husband's support.
\end{abstract}

Keywords : Phase 4 of pregnancy; antenatal care visits 


\section{Pendahuluan}

Keberhasilan upaya kesehatan ibu, di antaranya dapat dilihat dari indikator Angka Kematian Ibu (AKI). Indikator ini tidak hanya mampu menilai program kesehatan ibu, terlebih lagi mampu menilai derajat kesehatan masyarakat, karena sensitifitasnya terhadap perbaikan pelayanan kesehatan, baik dari sisi aksesibilitas maupun kualitas (Kemenkes RI, 2016).

Penurunan AKI di Indonesia terjadi sejak tahun 1991 sampai dengan 2007, yaitu dari 390 menjadi 228. Namun demikian, tahun 2012 menunjukkan peningkatan AKI yang signifikan yaitu menjadi 359 kematian ibu per 100.000 kelahiran hidup. AKI kembali menujukkan penurunan menjadi 305 kematian ibu per 100.000 kelahiran hidup pada tahun 2015 (Kemenkes RI, 2016).

Kasus kematian pada ibu dapat dicegah melalui pemeriksaan kehamilan secara rutin dan efektif serta melakukan persalinan ke pelayanan kesehatan. Pelayanan ANC (Antenatal Care) Penilaian terhadap pelaksanaan pelayanan kesehatan ibu hamil dapat dilakukan dengan melihat cakupan K1 dan K4. Indikator tersebut memperlihatkan akses pelayanan kesehatan terhadap ibu hamil dan tingkat kepatuhan ibu hamil dalam memeriksakan kehamilannya ke tenaga kesehatan. Cakupan pelayanan kesehatan ibu hamil K4 di Indonesia dari 86,85\% pada tahun 2013, terjadi penurunan $86,70 \%$ di tahun 2014, kemudian mengalami peningkatan kembali di tahun 2015 yaitu 87,48\% dan kembali terjadi penurunan di tahun 2016 yaitu 85,35\% (Kemenkes RI, 2016).

Cakupan pelayanan kesehatan ibu hamil K4 di Provinsi Sulawesi Tenggara menunjukan penurunan yaitu dari 80,5 pada tahun 2015 menjadi 73,96\% pada tahun 2016 . Bila mengacu pada target Restra Sultra sebesar 95\% cakupan K4 Provinsi Sulawesi Tenggara belum mencapai target. Sedangkan cakupan pelayanan kesehatan ibu hamil K4 di Konawe pada tahun 2016 sebesar 66,26\% (Dinkes Sultra, 2017)

Berdasarkan data dari Puskesmas Wawotobi, pada tahun 2017 dari bulan Januari sampai Desember di peroleh data jumlah ibu hamil sebanyak 716 ibu hamil dan cakupan K4 sebesar 55,5\% (338 ibu hamil dari jumlah sasaran 609 ibu hamil), pada tahun 2018 dari bulan Januari sampai Juli di peroleh data jumlah ibu hamil sebanyak 422 ibu hamil dan cakupan K4 sebesar 29,3\% (185 ibu hamil dari jumlah sasaran $631 \mathrm{ibu}$ hamil), walaupun belum sampai bulan Desember tapi jika dilihat dari jumlah sasaran ibu hamil dan mengacu pada target 
cakupan K4 Puskesmas Wawotobi tahun 2017 yaitu sebesar 95\% sangat jelas bahwa cakupan K4 di Puskesmas Wawotobi masih jauh dari target (Laporan KIA Puskesmas Wawotobi).

Sejauh penelusuran yang dilakukan oleh peneliti, ada beberapa penelitian yang telah dilakukan tentang faktor-faktor yang berhubungan dengan kunjungan pemeriksaan kehamilan (K4), perbedaan dengan penelitian sebelumnya terkait dengan variabel, cakupan K4 masih jauh dari target dan belum pernah dilakukan penelitian sejenis di Wilayah Kerja Puskesmas Wawotobi, Kabupaten Konawe, maka dari itu peneliti tertarik untuk melakukan penelitian tentang Faktor-faktor yang berhubungan dengan kunjungan pemeriksaan kehamilan (K4) di Wilayah Kerja Puskesmas Wawotobi, Kabupaten Konawe Tahun 2018.

\section{Tinjauan Teori}

Antenatal Care (ANC) merupakan suatu pelayanan yang diberikan oleh perawat kepada wanita selama hamil, misalnya dengan pemantauan kesehatan secara fisik, psikologis, termasuk pertumbuhan dan perkembangan janin serta mempersiapkan proses persalinan dan kelahiran supaya ibu siap mengahadapi peran baru sebagai orangtua (Wagiyo \& Putrono, 2016). Cakupan K4 adalah cakupan ibu hamil yang telah memperoleh pelayanan antenatal sesuai dengan standar, paling sedikit empat kali di suatu wilayah kerja pada kurun waktu tertentu (Kemenkes RI, 2016). Faktor-faktor yang berhubungan dengan Kunjungan Pemeriksaan kehamilan (K4) yaitu pendidikan, pekerjaan, paritas, jarak rumah kefasilitas kesehatan dan dukungan suami.

Tingkat pendidikan dapat meningkatkan akses ibu terhadap informasi, meningkatkan kemampuan dalam menerima konsep-konsep kesehatan yang baru dan interaksi yang baik dengan tenaga kesehatan. Tingkat pendidikan ibu dapat mempengaruhi kesadaran ibu dalam memanfaatkan sarana pelayanan kesehatan (Cholifah (2015)

Menurut Priani (2012) bahwa Ibu hamil yang tidak bekerja akan mempunyai waktu yang lebih banyak untuk melakukan aktivitasnya sehari-hari seperti pergi ke pelayanan kesehatan untuk memeriksakan kehamilannya, sedangkan pada ibu hamil yang bekerja akan memberikan kesibukan tambahan sehingga ibu hamil kadang tidak sempat memeriksakan kehamilannya

Menurut Rauf (2013) yang menjelaskan bahwa ibu hamil yang memanfaatkan pelayanan ANC dengan paritas tinggimengatakan bahwa terdapat risiko pada kehamilan sebelumnya sehingga merasa perlu untuk memeriksakan kehamilan secara teratur sedangkan 
ibu dengan paritas rendah yang kurang memanfaatkan pelayanan ANC mengatakan bahwa ia terlambat mengetahui tentang kehamilannya sehingga tidak memeriksakan kehamilan pada trimester pertama.

Jarak merupakan komponen kedua yang memungkinkan seseorang untuk memanfaatkan seseorang untuk memanfaatkan pelayanan pengobatan (Padila, 2014). Menurut penelitian Syamsiah (2014) yang menjelaskan bahwa dukungan suami mempengaruhi ibu hamil melakukan kunjungan ANC

\section{Metode Penelitian}

Tempat penelitian di Wilayah Kerja Puskesmas Wawotobi Kabupaten Konawe dan dilaksanakan pada bulan Agustus 2018. Penelitian ini menggunakan pendekatan kuantitatif menggunakan rancangan cross sectional. Sampel dalam penelitian ini adalah sebagian dari ibu hamil trimester III yang tinggal di Wilayah Kerja Puskesmas Wawotobi Kabpaten Konawe tahun 2018 berjumlah 42 responden. Teknik pengambilan sampel dilakukan dengan menggunakan Purposive Sampling. Variabel yang diteliti dalam penelitian ini adalah variabel dependen (kunjungan pemeriksaan kehamilan K4), dan variabel independen (pendidikan, pekerjaan, paritas, jarak rumah kefasilitas kesehatan, dukungan suami). Analisis penelitian menggunakan chi-square.

\section{Hasil Penelitian}

Hasil analisis bivariate faktor yang berhubungan dengan kunjungan pemeriksaan kehamilan (K4) dapat dilihat dalam tabel 1 berikut ini :

Tabel 1. Hasil Analisis Bivariat Faktor yang Berhubungan Dengan Kunjungan Pemeriksaan Kehamilan (K4)

\begin{tabular}{|c|c|c|c|c|c|c|}
\hline \multirow[t]{3}{*}{ No } & \multirow[t]{3}{*}{ Variabel } & \multicolumn{4}{|c|}{ Kunjungan pemeriksaan kehamilan K4 } & \multirow[t]{3}{*}{ p value } \\
\hline & & \multicolumn{2}{|c|}{ Lengkap } & \multicolumn{2}{|c|}{ Tidak Lengkap } & \\
\hline & & $\mathbf{n}$ & $\%$ & $\mathbf{n}$ & $\%$ & \\
\hline \multicolumn{7}{|c|}{ Pendidikan } \\
\hline 1 & Dasar & 5 & 12 & 15 & 35,71 & \\
\hline 2 & Menengah & 6 & 14,25 & 7 & 16,66 & 0,094 \\
\hline 3 & Tinggi & 6 & 14,25 & 3 & 7,14 & \\
\hline \multicolumn{7}{|c|}{ Pekerjaan } \\
\hline 1 & Bekerja & 5 & 12 & 13 & 31 & \\
\hline 2 & Tidak Bekerja & 12 & 28,5 & 12 & 28,5 & 0,257 \\
\hline
\end{tabular}




\begin{tabular}{|c|c|c|c|c|c|c|}
\hline \multirow[t]{3}{*}{ No } & \multirow[t]{3}{*}{ Variabel } & \multicolumn{4}{|c|}{ Kunjungan pemeriksaan kehamilan K4 } & \multirow[t]{3}{*}{ p value } \\
\hline & & \multicolumn{2}{|c|}{ Lengkap } & \multicolumn{2}{|c|}{ Tidak Lengkap } & \\
\hline & & $\mathbf{n}$ & $\%$ & $\mathbf{n}$ & $\%$ & \\
\hline \multicolumn{7}{|c|}{ Paritas } \\
\hline 1 & Primipara & 11 & 26,2 & 6 & 14,3 & \\
\hline 2 & Multipara & 5 & 11,9 & 11 & 26,2 & 0,019 \\
\hline 3 & Grandemultipara & 1 & 2,4 & 8 & 19 & \\
\hline \multicolumn{7}{|c|}{ Jarak rumah kefasilitas kesehatan } \\
\hline 1 & Jauh & 3 & 7,2 & 6 & 14,3 & \\
\hline 2 & Dekat & 4 & 33,3 & 19 & 45,2 & 0,716 \\
\hline \multicolumn{7}{|c|}{ Dukungan suami } \\
\hline 1 & Tidak mendukung & 5 & 11,9 & 18 & 42,9 & \\
\hline 2 & Mendukung & 12 & 28,6 & 7 & 16,6 & 0,016 \\
\hline
\end{tabular}

Hasil uji statistik pada tabel 1 menggunakan uji chi square antara paritas dan dukungan suami dengan kunjungan $\mathrm{K} 4$ diperoleh nilai $p$ value lebih kecil dari alpha 0,05 sehingga Ho ditolak, berarti ada hubungan yang signifikan antara paritas dan dukungan suami dengan kunjungan pemeriksaan kehamilan K4. Hasil uji statistik pada tabel 1 menggunakan uji chi square antara pendidikan, pekerjaan, dan jarak rumah ke fasilitas kesehatan dengan kunjungan $\mathrm{K} 4$ diperoleh nilai $p$ value lebih besar dari alpha 0,05 sehingga Ha ditolak, berarti tidak ada hubungan yang signifikan antara pendidikan, pekerjaan dan jarak rumah kefasilitas kesehatan dengan kunjungan pemeriksaan kehamilan K4.

\section{Pembahasan}

\section{Hubungan pendidikan responden dengan kunjungan pemeriksaan kehamilan K4}

Berdasarkan hasil uji statistik diperoleh nilai $\rho_{\text {value }}=0,094$, dengan demikin $\rho>0,05$ sehingga Ha ditolak, berarti tidak ada hubungan yang signifikan antara pendidikan dengan kunjungan pemeriksaan kehamilan K4. Tidak adanya hubungan pendidikan dengan kunjungan pemeriksaan kehamilan K4 disebabkan karena bukan hanya responden yang pendidikan dasar yang tidak melakukan kunjungan $\mathrm{K} 4$ akan tetapi responden yang pendidikan tinggi juga ada yang tidak melakukan kunjungan K4 sehingga responden yang pendidikan dasar, menengah, dan tinggi mempunyai peluang yang sama untuk melakukan kunjungan pemeriksaan kehamilan K4

Penelitian ini sejalan dengan penelitian yang dilakukan (Artika Dewie, 2016), yang menyatakan tidak ada hubungan yang signifikan antara pendidikan dengan kunjungan $\mathrm{K} 4$, itu berarti bahwa pendidikan ibu tidak berpengaruh terhadap kunjungan $\mathrm{K} 4$, dimana bukan hanya ibu yang berpendidikan tinggi saja yang melakukan kunjungan K4, tapi ibu dengan 
pendidikan rendah pun melakukan kunjungan K4. Penelitian ini juga sejalan dengan penelitan (Linda Yulyani, 2017), yang menyatakan bahwa tidak ada hubungan antara pendidikan ibu dengan kunjungan $\mathrm{K} 4$, pendidikan tinggi yang dimiliki oleh ibu memang merupakan faktor penting yang melatar belakangi dan memotivasi ibu hamil dalam melakukan pemeriksaan kehamilan secara teratur. Walaupun demikian, tidak berarti bahwa ibu hamil dengan status pendidikan rendah melakukan pemeriksaan kehamilan (K4) tidak sesuai standar

\section{Hubungan pekerjaan responden dengan kunjungan pemeriksaan kehamilan K4}

Berdasarkan hasil uji statistik diperoleh nilai $\rho_{\text {value }}=0,257$, dengan demikin $\rho>0,05$ sehingga Ha ditolak, berarti tidak ada hubungan yang signifikan antara pekerjaan dengan kunjungan pemeriksaan kehamilan K4. Tidak adanya hubungan pekerjaan dengan kunjungan pemeriksaan kehamilan K4 disebabkan karena bukan hanya ibu yang bekerja yang tidak melakukan kunjungan K4 akan tetapi ibu yang tidak bekerja yang seharusnya mempunyai banyak waktu luang untuk memeriksakan kehamilan juga ada yang tidak melakukan kunjungan pemeriksaan kehamilan K4, sehingga ibu yang bekerja maupun yang tidak bekerja mempunyai peluang yang sama untuk melakukan kunjungan pemeriksaan kehamilan.

Penelitian ini sejalan dengan penelitian yang dilakukan (Artika Dewie, 2016), yang menyatakan tidak ada hubungan yang signifikan antara pekerjaan dengan kunjungan $\mathrm{K} 4$, artinya ibu tersebut tidak bekerja ataupun bekerja, tidak mempengaruhi kunjungan K4. Dan juga sejalan dengan penelitian (Sumiati, 2012), yang menyatakan tidak terdapat hubungan yang signifikan antara pekerjaan ibu dengan kunjungan K4, hal ini mungkin saja karena ibu hamil yang bekerja maupun tidak bekerja memiliki pengetahuan yang baik tentang pentingnya pemeriksaan kehamilan, termasuk kunjungan $\mathrm{K} 4$, sehingga disela-sela kesibukannya, ibu hamil tesebut tetap menyisihkan waktu untuk melakukan pemeriksaan kehamilan. Penelitian ini juga sejalan dengan penelitian (Linda Yulyani, 2017) yang menyatakan bahwa tidak terdapat hubungan yang signifikan antara pekerjaan ibu dengan kunjungan K4. 


\section{Hubungan paritas responden dengan kunjungan pemeriksaan kehamilan K4}

Berdasarkan hasil uji statistik diperoleh nilai $\rho_{\text {value }}=0,019$, dengan demikin $\rho<0,05$ sehingga Ho ditolak, berarti ada hubungan yang signifikan antara paritas dengan kunjungan pemeriksaan kehamilan $\mathrm{K} 4$, hal ini disebabkan karena ibu primipara lebih banyak melakukan kunjungan kehamilan dibandingkan dengan ibu multipara maupun grandemultipara, dimana ibu primipara merasa lebih membutuhkan informasi mengenai kehamilannya dikarenakan mereka merasa belum berpengalaman pada kehamilan.

Penelitian ini sejalan dengan yang dilakukan (Linda Yulyani, 2017) yang menyatakan ada hubungan yang signifikan antara paritas dengan kunjungan K4, dimana paritas memiliki pengaruh yang kompleks terhadap inisiatif untuk melakukan kunjungan ANC, misalnya karena ketidaktahuan tentang tanda dan gejala kehamilan maka primigravida akan memilki usaha yang lebih untuk mencari tempat pemeriksaan dan melakukan ANC lebih dini.

Namun, penelitian ini tidak sejalan dengan penelitian (Artika Dewie, 2016), dengan $\rho_{\text {value }}=0,532$ yang menyatakan tidak ada hubungan yang signifikan antara paritas dengan kunjungan $\mathrm{K} 4$, berarti kondisi ibu dengan primipara maupun multipara tidak mempengaruhi kunjungan $\mathrm{K} 4$

Hubungan jarak rumah kefasilitas kesehatan dengan kunjungan pemeriksaan kehamilan K4

Berdasarkan hasil uji statistik diperoleh nilai $p$-value $=0,716$, dengan demikin $p>0,05$ sehingga Ha ditolak, berarti tidak ada hubungan yang signifikan antara jarak rumah kefasilitas kesehatan dengan kunjungan pemeriksaan kehamilan K4. Tidak adanya hubungan jarak dengan kunjungan K4 disebabkan karena bukan hanya responden yang jarak rumahnya jauh yang tidak melakukan kunjungan K4 akan tetapi responden yang jarak rumahnya dekat juga banyak yang tidak melakukan melakukan kunjungan kehamilan, sehingga responden yang jarak rumahnya jauh maupun dekat mempunyai peluang yang sama untuk menlakukan kunjungan pemeriksaan kehamilan K4.

Penelitian ini sejalan dengan penelitian yang dilakukan (Sumiati, 2012), yang menyatakan tidak terdapat hubungan yang signifikan antara jarak rumah ibu dengan kunjungan K4.Menurut (Sumiati, 2012) jarak dan waktu tempuh bukan menjadi prediktor terhadap aksesibiltas pada pelayanan kesehatan, artinya baik ibu yang memiliki persepsi 
waktu tempuh lama maupun dekat atau relatif cepat menjangkau tempat pelayanan memiliki peluang yang sama untuk berstatus pemeriksaan kehamilannya tidak lengkap.

\section{Hubungan dukungan suami dengan kunjungan pemeriksaan kehamilan K4}

Berdasarkan hasil uji statistik menggunakan uji chi square diperoleh nilai $p$-value = 0,016, dengan demikin $p<0,05$ sehingga Ho ditolak, berarti ada hubungan yang signifikan antara dukungan suami dengan kunjungan pemeriksaan kehamilan $\mathrm{K} 4$, hal ini disebabkan karena mayoritas ibu hamil yang melakukan kunjungan K4 lengkap yaitu yang mendapatkan dukungan suami, sehingga ibu termotivasi untuk melakukan kunjungan pemeriksaan.

Penelitian ini juga sejalan dengan penelitian (Sumiati, 2012) yang menyatakan ada hubungan yang signifikan antara dukungan suami dengan kunjungan K4, dimana dukungan suami sangat memegang peranan penting dalam perilaku ibu untuk melakukan pemeriksaan kehamilannya. Hal tersebut oleh karena kekhawatiran dari keluarga terhadap masa kehamilan yang merupakan gerbang untuk menghadapi persalinan, semakin baik pemeriksaan kehamilannya maka pihak keluarga akan semakin tenang untuk menghadapi persalinan, karena dapat mengetahui kondisi kehamilannya serta kesehatan ibu dan bayinya.

\section{Kesimpulan}

Faktor paritas dan dukungan suami merupakan faktor yang signifikan berhubungan dengan kunjungan pemeriksaan kehamilan K4 di Wilayah kerja Puskesmas Wawotobi Kabupaten Konawe tahun 2018.

\section{Saran}

Bagi Puskesmas Meningkatkan upaya promotif sepertikegiatan penyuluhan tentang pentingnya pemeriksaan kehamilan atau ANC kepada masyarakat oleh Perawat dan tenaga tenaga kesehatan lainnya sehingga pengetahuan masyarakat khususnya ibu hamil menjadi meningkat mengenai pentingnya melakukan kunjungan pemeriksaan kehamilan atau ANC, menganjurkan kepada ibu hamil untuk melakukan pemeriksaan kehamilan secara teratur minimal 4 kali kunjungan sesuai standart minimal kunjungan ANC

Bagi masyarakat dan ibu hamil agar ikut aktif hadir atau berperan serta apabila ada kegiatan penyuluhan, posyandu yang diselenggarakan oleh tenaga kesehatan dari Puskesmas 
khususnya penyuluhan tentang pemeriksaan kehamilan. Ibu hamil yang sudah mengetahui dan memahami pentingnya melakukan kunjungan ANC secara lengkap, maka harus mempertahankan sikap dan perilaku sehatnya selama kehamilan maupun pada kehamilan selanjutnya. Suami tetap mempertahankan dukungannya kepada istrinya yang sedang hamil sehingga ibu hamil mempunyai motivasi untuk melakukan pemeriksaan kehamilan ke petugas kesehatan secara rutin.

Bagi peneliti lain dapat menjadikan data pada penelitian ini sebagai data dasar bagi penelitiannya. Peneliti lain disarankan menambah variabel faktor predisposisi, faktor pemungkin, dan faktor penguat yang lain terhadap ibu melakukankunjugan ANC sehingga dapat diketahui faktor yang paling mempengaruhi keteraturan ibu hamil melakukan ANC. Peneliti lain disarankan melakukan penelitian di tempat lain yang memiliki kunjungan ANCrendah dengan metode atau desain yang berbeda, jumlah responden yang lebih besar.

\section{Daftar Pustaka}

Artika Dewi (2016). Faktor-Faktor Yang Mempengaruhi Kunjungan K4 Di Puskesmas Baqa Kota Samarinda Tahun 2016. Skripsi.Program Pasca Serjana. Samarinda.

BKKBN (2006).Buku Saku Bagi Petugas Lapangan Program KB Nasional Materi Konseling .BKKBN. Jakarta.

Cholifah, (2015), Faktor-faktor yang berpengaruh terhadap Pencapaian K4 di Desa Sumberejo Wonoayu Sidoarjo, Midwiferia Vol. 1 no. 02, Oktober 2015

Dairo, M., \& Owoyokun, K. E. (2010). Factors Affecting The Utilization Of Antenatal Care Service In Ibadan. Benin Journal of Postgraduate Medicine. Nigeria.

Dinkes Sultra (2017). Profil Kesehatan Sulawesi Tenggara Tahun 2016.Dinas Kesehatan Sulawesi Tenggara.Kendari.Sultra.

Green, L. W., \& Kreuter, M. W. (2005).Health Program Planning An Educational And Ecological Approach. Mc Graw Hill. New York

Kamus Besar Bahasa Indonesia.(2008). Departemen Pendidikan Nasional Edisi Ke-3. Balai Pustaka. Jakarta: Rineka Cipta

Kemenkes RI. (2016). Profil Kesehatan Indonesia Tahun 2016. Kementerian Kesehatan RI. Jakarta 
Linda Yulyani. (2017). Faktor-Faktor yang Berhubungan dengan Kunjungan K4 Pada Ibu Hamil di Puskesmas Danuragen. Skripsi.Program Pasca Serjana.Jogyakarta.

Mulyanti, L. (2010) .Hubungan Dukungan Suami Pada Ibu Hamil Dengan Kunjungan Anc Di Rumah Bersalin Bhakti Ibi Skripsi.Unimus. Semarang

Notoatmodjo S. (2010). Ilmu Prilaku Kesehatan. Jakarta : PT Rineka Cipta

Padila. (2014). Keperawatan Maternitas. Yogyakarta : Nuha Medika

Priani, Ika F (2012). Faktor-Faktor yang Mempengaruhi Keteraturan Ibu Hamil Melakukan Antenatal Care di Puskesmas Cimanggis Kota Depok.Skripsi. Fakultas Ilmu Keperawatan: UIDepok

Rauf, N. I., Amir, M. Y., Akk, B., \& Dkk. (2013).Factors Related To The Utilization Of Antenatal Care At Public Health Center Of Minasa Upa Makassar

Sumiati, S. (2012). Faktor-Faktor Yang Berhubungan Dengan Kunjungan Pemeriksaan Kehamilan K4 Di Puskesmas Dengan Perawatan Sindangratu Kabupaten Garut Tahun 2012.Skripsi. FKM UI.

Syamsiah,N\& Puspitasari, (2014). Faktor-Faktor Yang Berhubungan Dengan Kunjungan Antenatal Care Pada Ibu Hamil Di Puskesmas Kecamatan Kembangan Jakarta Barat Tahun 2014

Wagiyo dan Putrono.(2016). Asuhan Keperawatan Antenatal, Intranatal, dan Bayi Baru Lahir Fisiologis dan Patologis.Edisi pertama.Cetakan pertama.Yogyakarta : CV Andi Offset 